2020 APSA ANNUAL CONFERENCE PAPER

\title{
Thuggery, Sophisticated Impunity: Threats to Representative Democracy in Ghana
}

\section{Kojo Impraim}

\section{August 2020}

\begin{abstract}
The paper discusses patterns and dynamics of by-election violence and consequences on candidate selection in Ghana. Analysis of micro-level by-election violence as a factor of political thuggery, impunity and the effects on candidate selection remain scanty on Ghanaian politics. The paper analyses the problem using nine "violent" and nine "violent-free" by-elections between 1993 and 2019, and implications on voter turnout and margin of victory between National Democratic Congress (NDC) and New Patriotic Party (NPP). Voter turnout and margin of victory are low in "violent" by-election compared with "violent-free" parliamentary election in the same constituency, and "violent-free" by-elections in other constituencies. Election violence is incited by foot-soldiers of NDC and NPP. I attribute by-election violence to apparent weak commitment by the government to crack the whip by linking electoral injustice and impunity to the conduct of democratic election and law maintenance. The challenge speaks to institutionalisation, electoral reforms and the de-facto electoral competition of a simple majority benefiting from the entire political establishment. The paper is underpinned by the theory of political settlement. It concludes with lessons and implications for comparative and empirical literature.
\end{abstract}

Key words: Ghana; electoral violence; political vigilantism; political behaviour, representative democracy; New Patriotic Party; National Democratic Congress

${ }^{1}$ Phd Candidate, University of Cape Town, South Africa. Email: impraim.kojo.nana@gmail.com 


\section{Introduction}

Thuggery, electoral injustice and impunity have become a stance on Ghanaian politics. The practice is exacerbated by the first-past-the-post system of governance of a simple majority benefiting from the entire political establishment. The posturing has offered a convenient façade for political parties to compete for electoral space, not so much to demonstrate superiority of policy choices; rather to capture the commanding height of the state and control resources for mainly partisan considerations (see Ninsin, 2016).

The zero-sum political behaviour makes Ghana susceptible to election violence, within the spectrum of apparent stable democracy. Danso and Larty (2012) describe this as an anomaly of democratic consolidation. Political vigilantes act as self-appointed authority whose behaviour pose threats to election security and public safety in Ghana. They operate on the presumption that the law enforcement agency is weak. Where the cultural goals of security from violence cannot be attained because relying on the police is ineffective, radical groups take the laws into their hands, because they have low stake in conformity (Baker, 2002). Such radicalism has gained currency in electoral mobilisation in Ghana.

Ijon (2020: 36) argues that "just as elections in Ghana have become more competitive and participatory, they have also become more violent". The conduct of election has been characterised by varying degree of sporadic violence at each type of election-presidential, parliamentary, by-election, district level election, or even primaries, and at various phases of the election-pre, during, and post. The violence occurs mainly in the stronghold, competitive and hotspot $^{2}$ constituencies of the paties. Although observation reports by domestic and international organisations generally rate elections in Ghana as credible; amidst intermittent violence (see AU, 2016; CODEO, 2017).

The literature on micro-level election violence and impunity and the effects on candidate selection remain limited on Ghanaian politics. Few of these include Asamoah, 2020; Ijon, 2020; Kumah-Abiwu, 2017; Gyampo et el., 2017; Paalo, 2017; Bob-Milliar, 2014. The niche of this paper is a modest contribution to how by-election is fueled by violence and impunity, and the implications on candidate selection and representation. The paper first, analyses "violent" byelections and "violent-free" parliamentary elections in the same constituency and the effects on voter turnout and margin of victory between NDC and NPP. And second, juxtaposes "violent" by-elections with "violent-free" by-elections in other constituencies to reinforce the causal effect of violence on voter turnout and margin of victory between the two political parties.

Nine out of $31^{3}$ by-elections held in Ghana between 1993 and 2019 recorded violence. These were Wulensi (2003); Asawase (2005); Odododiodoo (2005); Akwatia (2008); Chereponi (2009); Atiwa (2010); Talensi (2015); Amenfi West (2015); and Ayawaso West Wuogon (2019) (Graphiconline.com, 2015; Ghanabusinessnews.com, 201; GhanaWeb, 2010; 2009; 2005). The

\footnotetext{
${ }^{2}$ Also known as flashpoints are high-risk geographical areas that are politically contentious, political battle grounds, competitive constituencies with characteristics of political frictions, and where organised crime is prevalent and potential ground for election violence (Ghana Police Service, 2020).

${ }^{3}$ Five out of 36 by-elections that occurred three months to the general elections were not conducted. The 1992 constitution of Ghana bares the Electoral Commission from conducting by-election three months to general election.
} 
violence was orchestrated by pro-NDC and pro-NPP thug as demonstrated in Table 3. Notorious behaviours of party thugs such as pro-NDC "Azorka Boys" and "Hawks", and pro-NPP "Bolga Bull Dogs" and "Invisible Forces" were dreadful. The violence took several forms including intimidation, assaults, arson, gunshots and use of other weapons resulting into vandalisation of properties, injuries and isolated cases of fatalities with some attributed to police inactions against the perpetrators (Ayee, 2017).

The paper is guided by the following questions: a) why the formation of political thuggeries for by-election violence in Ghana? and b) how does violence affects voter turnout and margin of victory between NDC and NPP in candidate selection? The paper is in two parts. Part one discusses the theoretical underpinnings of political thuggery and conceptual issues of election violence in Ghana. Part two deals with results and discussions. This is further structured into: a) micro-level by-election violence, and b) voter turnout and margin of victory between NDC and NPP during by-election. The paper is situated within the theory of political settlement and concludes with lessons and implications for comparative and empirical literature.

\section{The central argument}

In this paper, I use the expression "thuggery" synonymously with "political vigilantism". Election violence is symptomatic of thuggery. I argue that the escalating infiltration of thugs and radicalism into Ghanaian politics for political mobilisation, candidate selection and representation are threats, first, to the political groupings who established them, and second, to the state. Thuggery fuels impunity and electoral injustice. Thuggery "is a resource that is hired by the political parties to pursue opportunistic political gains regardless of law enforcement and the threats it poses to election security and democratic stability". The failure to link thuggery, electoral injustice and impunity to the conduct of democratic election, and law maintenance is a lacuna which affects the quality of normative politics and candidate selection in Ghana. This speaks to the challenge of institutionalisation and electoral reforms.

Thuggery is not a recent phenomenon. It has always characterised political struggle and post-1957 independence ascendancy by the political elites. For example, while Kwame Nkrumah-led Convention Peoples Party formed the "hoodlums" whose activities were considered by many citizens as violent against the opposition parties, the United Party formed the "action trooper"" to resist such attacks and protect its loyalists. A survey conducted by CDD in 2016, shows that seven out of 10 citizens were aware of the existence of political vigilantes associated with NDC, and $18 \%$ associated them to NPP. Also, seven out of 10 considered political vigilantism as a threat to democracy, peace and stability of Ghana.

The stake reality of Ghana's political settlement is the driving force of winner-takes-all electoral politics which is disingenuous to inclusive governance. Electoral victory means taking over the entire government machinery; control of power and assets depending on which party wins the presidential election. This political behaviour drives thuggery, electoral violence and 
impunity. As I depict in Figure 1, the behaviours of the "ruling coalition" and the party vigilantes affect credible election, security and law maintenance, and public safety.

Micro-level by-election violence entails physical and psychological behaviour that undermine the election integrity. I operationalise election violence "as an act of force measured or otherwise, harassment, and brutalities orchestrated by political grouping(s) and their cohort such as thugs, foot-soldiers and/or any radical network which harm voters and political opponents; and at the blind side of the police or the police and national security operatives compromise their stands to incite violence".

I posit that thuggery; election violence and impunity speak to the "wheels of electoral adjudication". It demands the imperative role of Electoral Commission (EC), police, and criminal administrative system to dispense justice speedily and impartially to regulate political behaviour. It also requires that the "coercive orders of constitutionalism" place a normative limit on political behaviour among competing parties. And rule of law must give expression to freedom from lawlessness (see Nina, 2000; Gerber and Jackson, 2017).

Figure 1: Candidate selection and by-election violence

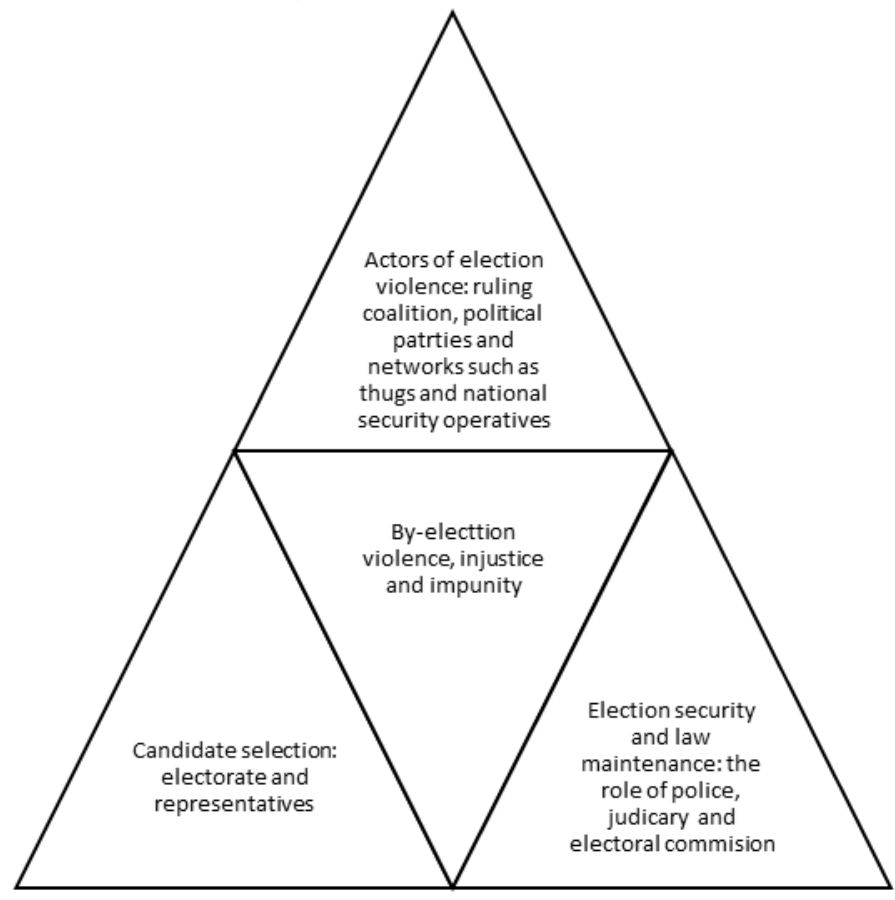

Source: Author's own construct, 2020

4 The set of actors whose contributions matter most and are often considered in policy formulation, implementation and other key decisions that affect the social, political and economic make-up of the country (Oduro et al., 2014). 


\section{The theoretical imperative}

The paper is situated within the theory of political settlement. Oduro et al., (2014) adopt the theory to identify the driving power relations of electoral politics in Ghana. The theory provides a framework for analysing institutional and governance challenges in developing countries. Khan describes political settlement as "social order" based on political compromises between powerful groups in the society that set the context for institutions and policies. He defines "political settlement as a combination of power and institutions that are mutually compatible and sustainable in terms of economic and political viability" (Khan, 2010: 4). Central to his argument is the distribution of "power" and the relative "holding power" of different groups and organisations contesting the distribution of national resources.

Ghana's political settlement according to Levy is characterised by a "competitive clientelist and patronage electoral politics driven by a ruling coalition (cited in Oduro et al. 2014: 2). The ruling coalition is made up of patrons who are the political elites and have the distributive powers of the national resources, and do so to favour the clients such as voters and party foot-soldiers (see Asamoah; 2020; Asante, 2012). The relationship between the ruling coalition (political elites) and the client (party vigilantes) is reciprocal. I reason that the nature of the "transactional politics" is consummated when the patrons are elected into political offices, and as a result of the power they wield in controlling state resources use them to reward their clients. As a result, the political settlement is characterised by intense mobilisation of identitybased groupings for electioneering deeply rooted in historical, ethnic, religious and regional cleavages (see Gyimah-Boadi and Debrah, 2008; Ninsin, 2008; Jonah, 2005; 1998). The intense electioneering drives several factors notably hate speech, party vigilantism and sporadic violence.

While political elites use campaign promises such as developmental projects to bait supporters for votes, networks such as party vigilantes demand pay-offs such as "job-for-theboys"; and failure to so do, they punish the parties through a heavy loss of votes. The contractual arrangement lubricates election violence. Sammy Awuku, the National Organiser of NPP is categorial that political vigilantes are formed to provide security for the parties especially protecting the ballots (Citinewsroom, 2017). Amankwah (2013) advances that the groups are organised armed or unarmed who are deployed as private forces by the political parties to

safeguard electoral prosperity. The application of the theory to the study helps to empirically understand how the conundrum of "distributive politics" between the patrons and the rank and file of the party fuels violence, impunity and the effects on voter turnout and margin of victory among competing parties during by-elections in Ghana.

\section{Conceptual explanation of election violence in Ghana}

Election harnesses political participation, competition and advancement of democratic maturity. While some studies consider election as the root cause of violence (Atwood, 2012), others consider it as alternative means to violence when conducted credibly (Fischer, 2002). Dunning (2011) underscores that election promotes conflict and as a tool for conflict resolution. 
Kwateng (2014: 84) notes that both the "ballot and bullet" have characterised the conduct of election in Africa and transfer of political power. Rapoport and Weinberg (2000: 16) reinforce that while election is "use to silence the gun, the ballot sometimes provokes the bullet". Election competition in Africa is ostensibly understood as "theatre of war" (Jinadu, 2014; Agbaje and Adejumobi, 2006 ).

UNDP (2011) interprets election violence as "any acts or threats of coercion, intimidation, or physical harm perpetrated to affect electoral process, or that arises in the context of electoral competition". The conceptual understanding of election violence is reiterated by Adolfo et al., (2012) as "coercive and deliberate strategy used by the political actors both incumbents and opposition to advance their interests or achieve specific political goals in relation to electoral contest". According to Ladan-Baki (2016) election violence entails "snatching of ballot boxes to rig and manipulate election results; causing pandemonium in the polling stations to hinder voters from voting; beating up electoral officials and sometimes killing same using weapons such as guns and cutlasses" (see Fischer 2002).

These perspectives largely cluster election violence into high-intensity and low-intensity. The categorisation connotes macro-level risk-factors (national) and micro-level risk-factors (local/community). Due to apparent weak institutions in many Africa states, violent-free election is in short supply. Political actors will "die to win" an election (Mueller, 2011) as they perceive victory as "their time to chop" (Lindberg, 2003). This presents macro-level outcomes such as political instability, turmoil and large-scale dislodgement of persons and properties (Bob-Milliar, 2014). Causes of macro-level election violence include patronage and exclusionary politics; winner-takes-all electoral competition; bad governance; historical, regional, ethnic, and religious clefts (Ninsin, 2006; Gyimah-Boadi, 2007; Boafo-Arthur, 2006; Huntington 1991); chieftaincy and land-based conflicts (Amankwaah, 2013; Danso and Lartey, 2012; Lund, 2003); among others causations.

Some studies, however, challenge the intensity of macro-level election violence in Africa. Straus and Taylor adopting a comprehensive dataset from African Electoral Violence Database (AEVD), rate election violence in Africa at 10\% from 1990 to 2008 of all elections conducted. The violence is orchestrated mostly by incumbency at pre-voting campaign period, and staged by three key actors - political parties, elite groups, and youth groups. They argued that political violence has declined, however not election violence (see Bob-Milliar, 2014b).

Bob-Millia (2014: 126a) operationalises micro-level violence or what he describes as low-intensity violence as a "keen competition between incumbent and challengers who manipulate the processes to gain advantage over each other with death toll not exceeding ten and no large-scale displacement of persons and dispossession of assets". He accentuates that lowintensity election is localised entailing infractions at the pre-voting and post-voting periods such as manipulation of electoral procedures, violent assault, breach of the peace, vandalisation of properties, stealing or stuffing of ballot boxes and other forms of electoral fraud. I contend that in Ghana, micro-level violence at by-election occurs mostly during the poll. As shown in Table 2 
and 3, nine out of 31 by-elections recorded violence on the election day caused by pro-NDC and NPP thugs, including National Security operatives, with weak law enforcement by the police.

Micro-level election violence in Ghana is erratic. It is caused by structural and vulnerability factors such as youth joblessness; unfilled electoral promises; social and local economic development conditions; survival political tactics (Bob-Milliar, 2014a); “issue framing" by political elites for electioneering (Kumah-Abiwu, 2017; Entman, 1993; Dery, 2000); formation of thugs for political mobilisation and policing the ballot box (Bob-Milliar, 2014a; Gyampo et el., 2017); divisive politics of losing power by the political elites, and mistrust between NDC and NPP, and towards the police and EC.

There is a growing weak public confidence in the police and application of rule of law by the judiciary to stamp out the culture of electoral injustice and impunity. The 2014 Afrobarometer reports that only $18 \%$ of Ghanaians have confidence in the police (Parku, 2014). Mistrust heightens election violence and impunity. This is exacerbated by the practice of firstpast-the-post system of governance which pervasively exhibits intense political rivalry between NDC and NPP over election as "theatre of war", but not as "theatre of heathy competition" where winning or losing political contest is part of the democratic process that propels a country on the path of democratic maturity.

I remark that even though, election violence largely occurs at the micro-level in Ghana, it does not in any way immune the country from high-intensity election violence as both causes are interlinked, and the micro-level causes are symptomatic of the macro-level factors. The Centre for African Democratic Affairs (CADA) records 5,707 different forms of election violence in Ghana between 1992 and 2012 out of which assault and violent intimidation accounts for $49.1 \%$ as shown in Table 1. Bob-Milliar (2014a) corroborates the findings with a catalogue of election violence in the same period comprising-ballot box theft (142); molestations/violent intimidation (2807); seizure/public properties occupancy (1812); protests/public disorders (858), and party property vandalisation (88). The violence was mainly staged by foot-soldiers of NDC and NPP which disenfranchised some voters from participating in the election, suppressed political rights of voters to choose preferred candidates, discredited votes in the polling stations, disrupted the electoral process, or used as caveat to seek retribution for political support or votes cast.

Table 1: Incidence of election violence in Ghana from 1992 to 2012

\begin{tabular}{|l|l|l|}
\hline Type of Violence & Number of Incidents & Percentage of Total \\
\hline Assault/Violent Intimidation & 2,807 & $49.1 \%$ \\
\hline Seizure of Public Property & 1,812 & $31.7 \%$ \\
\hline Protests/Public Disorders & 858 & $15.0 \%$ \\
\hline Ballot Box Theft & 142 & $2.4 \%$ \\
\hline Party Property Vandalisation & 88 & $1.5 \%$ \\
\hline Total & 5,707 & \\
\hline
\end{tabular}

Source: Centre for African Democratic Affairs, 2018; Bob-Milliar, 2014. 
Further analysis of Table 1 indicates that incidence of violence cut across both general and byelections in Ghana. As shown in Figure 2, the highest incidence of election violence (1182) was recorded in 2009. Incidence of "seizure and occupancy of public properties" recoded highest (765) in the same year, while incidence of "assault and violent intimidation" were highest (468) in 1992. Incidence of election violence declined relatively from 573 in 1992, however upsurge in 2009. Election violence in Ghana has decreased significantly from 1182 in 2009 to 104 as of 2012. "Ballot box snatching" has also expressively lessened from 1992 to 2012. It is also observed that incidence of violence is high during "transition elections" (Ninsin, 2016) and political transitions (with 2009, 1992, and 2001) recoding the highest in that order.

The violence is mostly ignited by electoral malpractices such as vote buying, allegations of double voting, ballot snatching, conveying non-indigenes to the constituency to vote, hate speech among others drivers. NCCE's 2011 survey notes that the preoccupation of the party foot-soldiers is "movement from one polling station to the other with the aim to intimidate opponents and scare off the electorate with their nefarious activities".

Figure 2: Incidence of election violence from 1992 to 2012

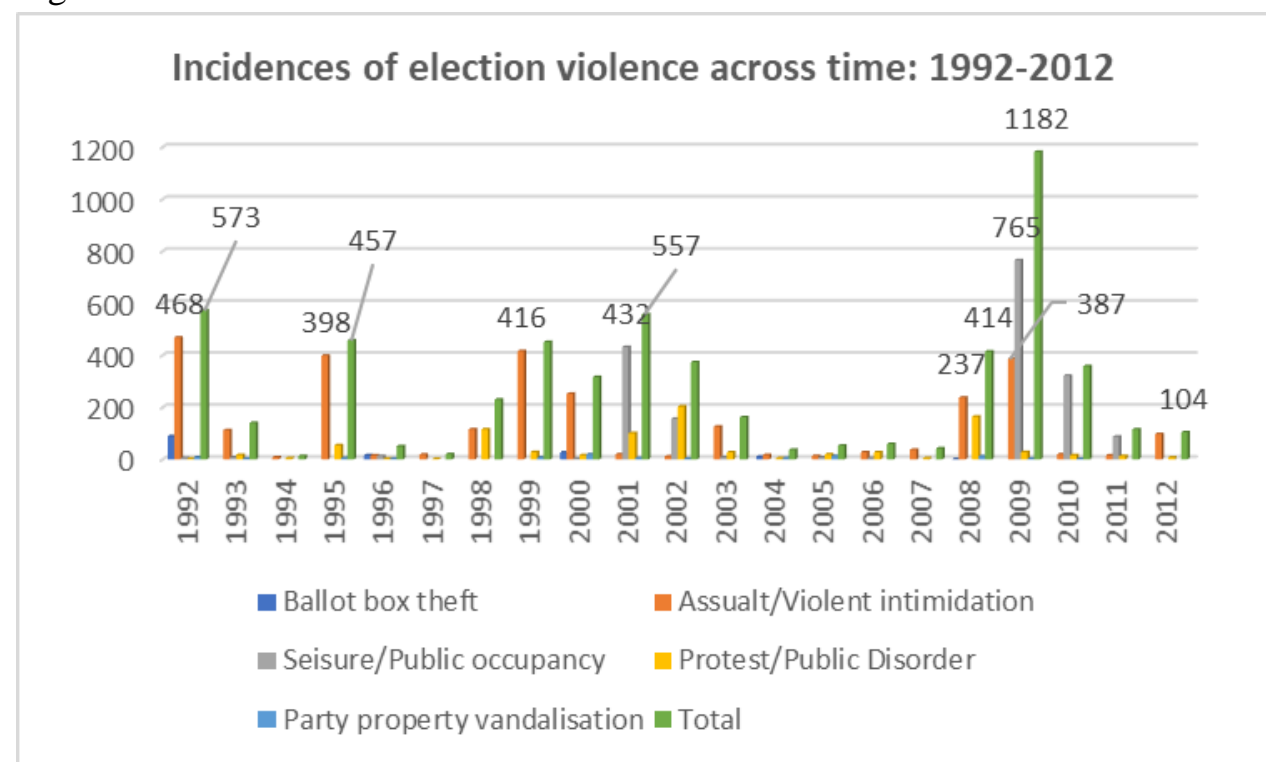

Source: Author's own construct using raw data from CADA, 2018; Bob-Milliar, 2014.

Micro-election violence is also a factor of unprofessional media rapportage and miscommunication. These include fake and bias news coverage, calling election results, misrepresentation of public discourse on political issues by some media houses via print, television, radio, and new media publications. Such rapportage fuel polarisation, tensions and violence. Aubyn and Abdallah (2013 citing Frempong, 2019) report that the police struggled to maintain law and order during elections; For example, in 2008 general election following rampage and lawlessness by the supporters of NDC and NPP. The disorder was preceded by bias 
media rapportage by pro-NDC and pro-NPP radio stations towards the election which caused the supporters to besiege the stations.

Inaccurate and misleading election reports by the media tend to inflame passions and provoke violence among supporters of the political parties. Unsubstantiated media reports and predispositions create panic and confusion at some of the polling centers as people rush to those centres to ascertain the veracity of those media claims (see NCCE, 2011). This sometimes led to open confrontation between supporters of NDC and NPP, and between party vigilantes and the security personnel which often irritate warning shots and teargas from the police to disperse the crowd.

Again, by-election violence is intensified by bussing of executives and supporters of competing political parties from the party headquarters, regional offices and other constituencies to join forces with local support-base at the constituency whenever election is taking place. The posturing most of the times precedes with mounting of road blocks by supporters of NDC and NPP to inspect and flush out non-residents and political opponents entering the constituency. This generates clashes and violence between party supporters as was the case in 2010 Atiwa byelection.

Winning election at all cost is a "rat race" between NDC and NPP. Aggregating party thugs to guard the ballot boxes is a compelling business case. Election violence revolves around actors, motives, consequence and patterns of political behaviour. In recent times, the court of public opinion has raised concerns about the potency of by-election in Ghana in the face of several violence that are fumed by pro-NDC and pro-NPP vigilantes. Some argue that anytime a constituency seat becomes vacant, the party holding the seat should be allowed to replace it automatically, which would potentially reduce the risk of violence as well as make savings for the country. Studies by NCCE (2011) on political vigilantism and Ijon (2020) on by-elections in Talensi and Ayawaso West Wougon constituencies corroborate such opinion. However, such argument would require constitutional alteration as Ghana practices a single-member constituency where the electorate vote for their representatives and not the political parties. In some cases, independent candidates have won the election to represent the constituency in the parliament.

\section{What accounts for the formation of political thuggeries?}

How does thuggery promote the interests of political parties, financiers and the thugs? Thuggery is financed through several sources. While the group have financiers from their political masters, members pay registration fees. A survey conducted by CDD and UNDP in 2019 reveals that party thugs in Sakore (Brong region), Yendi (Northern region), and Afloa (Volta region) pay a minimum of One Thousand Two Hundred Ghana Cedis (GHS1200.00) equivalent of USD 220 as registration fees. Akwetey attributes the formation of thuggery to the failure of political parties to disclose the sources of financing as required by law. The bankrollers are alleged to be

providing financial support to vigilantes, making it difficult to eradicate the menace, as the groups wield unfettered powers (Classfmonline.com, 2018). 
Thuggery is also an attribute of limited economic and job opportunities for the youth. Unemployed youth are "reserved army" who are exploited by the political class. Several statesmen and security analysts have raised alarm over Ghana's deteriorating security situation. And warn the risk of the country sliding into anarchy if immediate steps were not taken to address what they describe as "worsening youth unemployment and youth hopelessness, and the threat they pose to peace and stability" (ICU, 2017).

Majority of the youth who form the core base of the party foot-soldiers have belowaverage educational qualification or none at all and without secure employment (Bob-Milliar (2014a). They therefore fall prey to the politicians who employ them to execute services such as canvas for votes and mobilisation. Those with exceptional mobilisation qualities graduate into membership status and acquire leadership positions such as youth organiser, constituency organiser, or local chairman. For example, Chief Sofo Azorka who won the Northern Regional Chairmanship position of NDC in 2010, and the Deputy National Vice Chairman as of 2020 was hitherto the former leader of pro-NDC thugs "Azorka Boys".

Party vigilantes perform additional responsibilities as security officers at the party headoffice, regional and constituencies offices, primaries, congress, rallies, press conference, and demonstration. They also serve as polling agents and as errand boys such as bodyguards and personal drivers to some of the political elites. Even where the services of the police are sought for by the political parties in these events, the party thugs act alongside clandestinely, which further exposes mistrust political parties have towards the police. The relationship between the political class and the thugs is based on shared benefit. The thugs understanding of their patrons is that they are wealthy and control the public purse; therefore, the resources should be used to reward them when they win elections.

Thuggery gives access to the corridors of political power, recognition within the party, and protection from the law (see CDD and UNDP, 2020). Aning reiterates that "it transforms lives, create new identities, give access to power, and one of the most stable currencies in Ghana" (see Justice Emile Short Commission, 2019). The party foot-soldiers have learnt to maximise their usefulness beyond being exploited by the politicians by effectively using the tools of violence at the disposal of the political elites. Other rewards confer on the party vigilantes according to Bob-Milliar (2014a: 133) are monetary and introductory letters from the office of the "Honourable" Member of Parliament (MP), or Minister of State or "protocol list" from the Office of Chief of Staff or National Party Chairman will facilitate smooth selection of vigilantists into security services such as national security, police, army, or as revenue/tollbooth/market collectors, and cleaners even when they do not meet the selection criteria.

Political vigilantism has gained considerable root in Ghana. Appendix 1 presents 48 political vigilante groups visibly connect with Ghanaian politics since 1957 till date. While 26 of the groups are associated with NDC, 14 of them are connected to NPP, and eight of them operated from 1957 throughout 1992. The sphere of influence and location of the groups are mostly in the hotspot regions notably Greater Accra, Ashanti, Northern, Ahafo and Eastern. 


\section{Data and Method}

Article 66(1) of the 1992 constitution stipulates the conduct of by-election in Ghana. The article also spells out requirements for the conduct of by-election, that is, when an MP dies, resigns or is debilitated to perform his or her duties. In any of these cases, parliamentary election is held in the affected constituency to determine a replacement. Article 112 (5) of the constitution further stipulates that whenever a vacancy occurs in the parliament, the Clerk of Parliament shall notify the EC in writing within seven days after becoming aware that the vacancy has occurred; and by-election shall be held within 30 days after the vacancy occurred except where the vacancy occurred by death; the by-election shall be held within 60 days after the occurrence of the vacancy (Ghana Constitution, 1992). Ghana practices a single-member constituency; therefore, the vacant position is filled through competitive election among political parties.

The paper principally dwells on descriptive data from academic sources, public domain from statutory bodies and media houses reports to analyse political thuggery, election violence, and impunity in candidate selection during by-elections in Ghana. It also adopts a case study approach and content analysis of by-elections in Ghana using nine "violent" and nine "violentfree" by-elections out of 31 conducted between 1993 and 2019. It studies the implications of these by-elections on voter turnout and margin of victory between NDC and NPP. The analysis entails a comparism of "violent" by-election and "violent-free" parliamentary election in same constituency, and juxtaposes it with "violent-free" by-elections in other constituencies.

\section{Limitation of the study}

The selection of case studies was based on the attributes of availability of literature, the intensity of violence, voter turnout and margin of victory between NDC and NPP in violent byelection. Data was however unavailable to significantly interrogate the dynamism of election security breaches by the police and national security operatives and the threats they pose to candidate selection. This is area for further research.

\section{Results and Discussions}

\section{Micro-level by-election violence and effects on candidate selection}

Ghana's seventh parliament began in 2016. The first parliament commenced in 1993. Three transfers of political power have taken place between two competing parties, i.e. NPP (2000/2001), NDC (2008/2009), NPP (20016/2017), however, NDC ruled from the first parliament. Table 2 shows 36 vacant parliamentary seats from the first to the seventh parliament. By-elections were conducted in 31 constituencies. Twenty-one of the by-elections were carried out under the governorship of NDC and 15 under NPP regime. Nine (29\%) of the by-elections were violent-driven. Four of the by-elections recorded violent during NDC regime and 5 under NPP. Four occurred in NDC strongholds, three in NPP strongholds, and two in competitive constituencies. 
Five of the vacant seats were not filled. These were attributed to following reasonsconstitutional requirements; the 1992 constitution barres EC from conducting by-election in effected constituency three months to general election. Other seats became vacant due to resignation, and incarceration of MPs. Other MPs had their residency and dual citizenship challenged at the court. Some also cross carpeted. Some of the affected constituencies were Ho West in 1996, Ashanti Akim North in 2008, Wulensi in 2012, Kwabre West in 2012 and Bawku Central in 2012. Death accounted for $22(61 \%)$ of the vacant seats (see Ijon, 2020).

The nature of the election violence at both general and by-election are similar. These include random and organised violence by NDC and NPP thugs which take the form of verbal intimidations, physical assaults, rampage, mounting of road blocks, singeing tyres, arson, gunshots, forced protection, and destruction of properties such as electoral materials, vehicles, and parties' constituency offices and symbols mostly on election day. The violence psychologically traumatized voters, including harassment and beatings of electoral officials, journalists and party executives. Injuries including reported cases of deaths involving perpetrators are recorded with some attributed to collusion between party thugs and the police and national security operatives (Ijon, 2020; Kumah-Abiwu, 2017; Ayee, 2017; Gyampo et el., 2017; Paalo, 2017; Bob-Milliar, 2014a). This observation contradicts postulation by Laakso and Straus and Taylor that election violence is primarily caused by the incumbency at pre-voting campaign period (see Laakso, 2019).

Election violence pose barrier to candidate selection including women's political participation (Darkwa, 2012). They serve as inhibiting factor to the ability of female politicians to compete fairly and openly with their male counterparts which often leads to their disqualification, defeat, or lack of interest. Besides, poor investigation and adjudication of electoral offences make it difficult for female candidates to contest effectively with male candidates.

By-election violence affects voter participation in the election and winning chances of competing parties. For example, the NDC candidate Delali Kwesi Brempong for 2019 Ayawaso West Wuogon by-election, complained of brutalities from the national security operatives and pro-NPP thugs "Invincible Forces", which affected his chances of winning the election with only $30.52 \%$ votes compared with his competitor Lydia Alhassan who pulled 68.80\%. Samuel Ofosu Ampofo, the National Chairman of NDC, noted that "armed security men besieged the candidate's house at La Bawalashie, a suburb of Accra metropolis; and the party could no longer guarantee the security of its supporters and polling agents" (WANEP, 2019; CDD, 2019; BBC, 2019; Issafrica.org, 2009).

Again, CDD (2005) attributes low voter turnout (57\%) in August 2005 Odododiodoo byelection compared with $83 \%$ in December 2004 parliamentary election to heavy presence of security personnel with the use of sirens and armoured cars allegedly created tension and intimidated voters, in addition to violence by party thugs. Also, low voter turn-out (64\%) in 2005 Asawase by-election compared with $70 \%$ in 2004 parliamentary elections was linked to violence between NDC and NPP party thugs, and police brutalities (Graphic Online, 2005). 
Evidence of police collusion, vagaries of teargases and gunshot against perpetrators were also established in 2015 Talensi and 2019 Ayawaso West Wougon by-elections (Ijon, 2020: WANEP, 2019; Myjoyonline.com, 2019). Aside from the clashes between NDC "Azorka Boys" and "Hawks", and NPP "Bolga Bull Dogs" and "Invisible Forces" in these two by-elections, both NDC and NPP exploited incumbent advantage using the National Security operatives (SWAT Team) to escalate the violence.

The involvement of security agencies in election violence speaks to weak public confidence in law enforcement. Ijon (2020) describes the security operatives as "state-sponsored terrors" who are mobilised through the party machinery to cause electoral injustice and impunity. Some of the security personnel have been cited using unauthorise weapons during the violence which was a culpable offence against the Criminal Offence Act, Section 192(1). For example, Justice Emile Short Commission 2019, fingered Ernest Akomea, a member of SWAT Unit possessing offensive firearms during the Ayawaso West Wuogon by-election shooting incidence. I assert that police ferocity in election violence is hypocritical to political rights of voters, which disenfranchise them and further lead to low voter turnout, and affect margin of victory among competing parties. Such inactions contribute to the denial of democratic rights and franchise of citizenry which is against the spirit and the letter of the 1992 constitution of Ghana (see NCCE, 2011).

Table 2: By-elections conducted in Ghana from 1993 to 2019

\begin{tabular}{|c|c|c|c|c|c|}
\hline Parliament & $\begin{array}{l}\text { Governing } \\
\text { party }\end{array}$ & $\begin{array}{l}\text { Number of } \\
\text { vacant } \\
\text { parliamentary } \\
\text { seats }\end{array}$ & $\begin{array}{l}\text { Constituencies } \\
\text { where violence } \\
\text { occurred }\end{array}$ & $\begin{array}{l}\text { Winning } \\
\text { party }\end{array}$ & $\begin{array}{ll}\text { Stronghold } & \text { or } \\
\text { competitive } & \\
\text { constituency } & \end{array}$ \\
\hline First parliament: $1993-9996$ & NDC & 5 vacancies & No violence & - & - \\
\hline Second parliament: 1997-2000 & NDC & 2 vacancies & No violence & - & - \\
\hline Third parliament: 2001-2004 & NPP & 7 vacancies & Wulensi (2003) & NPP & Competitive \\
\hline Fourth parliament: $2005-2008$ & NPP & 7 vacancies & $\begin{array}{l}\text { Asawase (2005); } \\
\text { Odododiodoo } \\
(2005) ; \\
\text { Akwatia (2009) }\end{array}$ & $\begin{array}{l}\text { NDC } \\
\text { NDC } \\
\text { NPP }\end{array}$ & $\begin{array}{l}\text { NDC Stronghold; } \\
\text { NDC Stronghold; } \\
\text { NPP Stronghold }\end{array}$ \\
\hline Fifth parliament: $2009-2012$ & $\mathrm{NDC}$ & 7 vacancies & $\begin{array}{l}\text { Chereponi (2009); } \\
\text { Atiwa (2010) }\end{array}$ & $\begin{array}{l}\text { NDC } \\
\text { NPP }\end{array}$ & $\begin{array}{l}\text { Competitive } \\
\text { NPP Stronghold }\end{array}$ \\
\hline Sixth parliament: $2013-2016$ & NDC & 7 vacancies & $\begin{array}{lr}\text { Talensi } & (2015) ; \\
\text { Amenfi } & \text { West } \\
(2015) & \end{array}$ & $\begin{array}{l}\text { NDC } \\
\text { NDC }\end{array}$ & $\begin{array}{l}\text { NDC Stronghold; } \\
\text { NDC Stronghold }\end{array}$ \\
\hline $\begin{array}{l}\text { Seventh parliament: 2017- } \\
2020\end{array}$ & NPP & 1 vacancy & $\begin{array}{l}\text { Ayawaso West } \\
\text { Wuogon (2019) }\end{array}$ & NPP & NPP Stronghold \\
\hline
\end{tabular}

Source: author's own compilation, 2020 


\section{Parliamentary and by-election results and voter turnout}

\section{By-elections and voter turnout}

This section discusses voter turnout at candidates' selection between NDC and NPP as shown in Table 3. It analyses nine "violent" and nine "violent-free" by-elections out of 31 conducted in Ghana between 1993 and 2019. It also analyses the voter turnout in "violent" byelections and compared them with "violent-free" parliamentary elections in same constituency from 2000 to 2019. The Table presents from the top the highest to the lowest voter turnout and percentage obtained at each election by NDC and NPP. Again, the study compares the voter turnout at by-election with "prior parliamentary election" and subsequent parliamentary elections, that is, "post-by-election" in the same constituency. Voter turnout in the nine "violent" by-elections reduced compared with the "violent-free" parliamentary elections. The violence mostly occurs in the stronghold constituencies of NDC and NPP.

I operationalise "stronghold" and "competitive" constituencies using the following variables: a) "where the margin of electoral victory is less than or equal to $(\leq) 10 \%$, the constituency is "competitive", b) where the margin of electoral victory is greater than (>) $10 \%$, the constituency is "stronghold," and c) where one particular party repeatedly wins the election the constituency is its "stronghold". Stronghold constituency can be held by either incumbent or opposition party.

The operational definition shows that NPP won the 2010 Atiwa by-election in its stronghold at $53.3 \%$ voter turnout while in opposition. Also, NDC whether in opposition or in government wins the Asawase constituency election as its traditional seat in the stronghold region (Ashanti region) of NPP. Voter turnout in the "violent by-election" at Atiwa was 27,540 compared with 34,931 (74.2\%) in 2008 "violent-free" parliamentary election. Similarly, the voter turnout in a "violent by-election" at Asawase in 2005 was lower 51,635 (64.29\%) compared with $(67,485(84.5 \%)$ in 2004 and 64,943 (69.1\%) in 2008 "violent-free" parliamentary elections.

Again, the 2015 Talensi by-election was characterised by violence and recorded a voter turnout of 24,499 . This represents a reduction of 2,951 from 27,450 voter turnout in "violentfree" 2012 parliamentary election and much higher voter turnout (31,700 (72\%)) in 2016 election. While Chereponi recorded a voter turnout of 16,186 (31.3\%) in 2009 "violent" byelection, its performance in 2008 and 2012 parliamentary elections was higher at 18,615 and 22,683 respectively. Voter turnout in 2019 Ayawaso West Wuogon by-election was abysmally recorded at $17,589(19.83 \%)$ due to violence, compared with "violent-free" parliamentary elections in 2012 and 2016 with 63,232 and 57,053 voter turnouts respectively. 
Table 3: Selected cases of parliamentary and by-elections results and voter turnout

\begin{tabular}{|c|c|c|c|c|c|c|}
\hline $\begin{array}{l}\text { Parliamentary and constituency by- } \\
\text { election }\end{array}$ & $\begin{array}{l}\text { NDC } \\
\text { votes }\end{array}$ & $\begin{array}{l}\% \text { of } \\
\text { votes }\end{array}$ & $\begin{array}{l}\text { NPP } \\
\text { votes }\end{array}$ & $\begin{array}{l}\% \\
\text { Votes }\end{array}$ & $\begin{array}{l}\text { Voter } \\
\text { Turn out }\end{array}$ & $\begin{array}{l}\text { \% voter } \\
\text { turnout }\end{array}$ \\
\hline 2016 Talensi parliamentary & 12,874 & 41.68 & 8,382 & 27.13 & 31,700 & 72.0 \\
\hline 2012 Talensi parliamentary & 9,119 & 33.22 & 11,380 & 41.46 & 27,450 & -5 \\
\hline 7 July 2015 Talensi by-election & 10,366 & 42.31 & 6,845 & 29.94 & 24,499 & - \\
\hline 2004 Asawase parliamentary & 33,541 & 49.7 & 29,067 & 43.1 & 67,485 & 84 \\
\hline 2008 Asawase parliamentary & 36,557 & 56.7 & 27,168 & 42.2 & 64,943 & 69.1 \\
\hline 21 April, 2005 Asawase by- election & 31,017 & 60.4 & 19,875 & 38.7 & 51,635 & 64.29 \\
\hline 2004 Odododiodoo parliamentary & 35,634 & 52.4 & 31,546 & 46.4 & 67,994 & 83.3 \\
\hline 2008 Odododiodoo parliamentary & 34,182 & 55.7 & 25,495 & 41.5 & 61,613 & 65.9 \\
\hline $\begin{array}{l}30 \text { August } 2005 \text { Odododiodoo } \\
\text { by-election }\end{array}$ & 26,841 & 57.9 & 18,464 & 39.8 & 46,991 & 57.6 \\
\hline 2012 Chereponi parliamentary & 10,565 & 46.58 & 11,680 & 51.49 & 22,683 & - \\
\hline 2008 Chereponi parliamentary & 7,648 & 43.6 & 9,188 & 52.3 & 18,615 & 80.0 \\
\hline $\begin{array}{l}29 \text { September } 2009 \text { Chereponi } \\
\text { by-election }\end{array}$ & 8,239 & 50.9 & 7,416 & 45.8 & 16,186 & 71.3 \\
\hline 2008 Atiwa parliamentary & 7,851 & 22.7 & 26,423 & 76.4 & 34,931 & 74.2 \\
\hline 2010 Atiwa by-election & 6,190 & 22.9 & 20,282 & 75.0 & 27,540 & 53.3 \\
\hline 2012 parliamentary (Atiwa West) & 5,984 & 25.84 & 17,176 & 74.16 & 23,160 & - \\
\hline $\begin{array}{l}2012 \quad \begin{array}{l}\text { Ayawaso West } \\
\text { parliamentary }\end{array} \\
\end{array}$ & 30,116 & 47.63 & 31,807 & 50.30 & 63,232 & - \\
\hline $\begin{array}{l}2016 \quad \text { Ayawaso West } \text { Wuogon } \\
\text { parliamentary }\end{array}$ & 22,534 & 39.63 & 32,591 & 57.32 & 57,053 & 64 \\
\hline $\begin{array}{lccc}31 & \text { January } 2019 & \text { Ayawaso } & \text { West } \\
\text { Wuogon by-election } & & \\
\end{array}$ & 5,341 & 30.52 & 12,041 & 68.80 & 17,589 & 19.83 \\
\hline 2012 Akwatia parliamentary & 20,471 & 50.44 & 19,914 & 49.07 & 40,586 & - \\
\hline 2004 Akwatia parliamentary & 17,484 & 45.5 & 19,386 & 51.6 & 37,135 & 90.2 \\
\hline 2009 Akwatia by-election & 15,860 & - & 17,900 & - & - & - \\
\hline 2012 Amenfi West parliamentary & 26,435 & 60.55 & 16,829 & 38.54 & 43,661 & \\
\hline 2016 Amenfi West parliamentary & 23,673 & 56.87 & 17,363 & 41.65 & 42,215 & 64.0 \\
\hline 2015 Amenfi West by-election & 15,809 & 52.64 & 13,076 & 43.54 & 30,561 & 49.0 \\
\hline 2004 Wulensi parliamentary election & 9,864 & 43.7 & 10,476 & 46.4 & 23,754 & 89.0 \\
\hline 20 February 2003 Wulensi by-election & 7,303 & 45.0 & 8,197 & 50.5 & 16,798 & 58.1 \\
\hline 2000 Wulensi parliamentary election & 9,537 & 54.4 & 6,884 & 39.3 & - & - \\
\hline
\end{tabular}

Source: author's compilation from EC website; media sources, 2020

In Table 4 and 5, the analysis juxtaposes the voter turnout in nine "violent" by-elections with nine "violent-free" by-election conducted from 2003 to 2019 at different constituencies. Again, voter turnout moderately reduces in "violent" by-elections compared with "violent-free byelection within the period. Voter turnout reduced significantly in the stronghold constituencies of the parties such as Ayawaso West Wuogon by-election (19.83\%). In some of the by-elections, NPP and NDC did not participate which contributed to the reduction in the voter turnout as depicted in Table 5.

\footnotetext{
${ }^{5}$ Data unavailable
} 
Table 4: "Violent" by-elections results and voter turnout from 2003 to 2019

\begin{tabular}{|l|l|l|l|l|l|l|l|}
\hline $\begin{array}{l}\text { Parliamentary and constituency by- } \\
\text { election }\end{array}$ & $\begin{array}{l}\text { NDC } \\
\text { votes }\end{array}$ & $\begin{array}{l}\text { \% of } \\
\text { votes }\end{array}$ & $\begin{array}{l}\text { NPP } \\
\text { votes }\end{array}$ & $\begin{array}{l}\text { \% } \\
\text { Votes }\end{array}$ & $\begin{array}{l}\text { Voter } \\
\text { Turn out }\end{array}$ & $\begin{array}{l}\text { \% voter } \\
\text { turnout }\end{array}$ & $\begin{array}{l}\text { Nature of } \\
\text { constituency }\end{array}$ \\
\hline 7 July 2015 Talensi by-election & 10,366 & 42.31 & 6,845 & 29.94 & 24,499 & - & $\begin{array}{l}\text { NDC } \\
\text { stronghold }\end{array}$ \\
\hline $\begin{array}{l}\text { 29 September 2009 Chereponi } \\
\text { by-election }\end{array}$ & 8,239 & 50.9 & 7,416 & 45.8 & 16,186 & 71.3 & Competitive \\
\hline 21 April, 2005 Asawase by- election & 31,017 & 60.4 & 19,875 & 38.7 & 51,635 & 64.29 & $\begin{array}{l}\text { NDC } \\
\text { stronghold }\end{array}$ \\
\hline 20 February 2003 Wulensi by-election & 7,303 & 45.0 & 8,197 & 50.5 & 16,798 & 58.1 & Competitive \\
\hline $\begin{array}{l}\text { 30 August 2005 Odododiodoo } \\
\text { by-election }\end{array}$ & 26,841 & 57.9 & 18,464 & 39.8 & 46,991 & 57.6 & $\begin{array}{l}\text { NDC } \\
\text { stronghold }\end{array}$ \\
\hline $\begin{array}{l}\text { 17 November 2015 Amenfi West by- } \\
\text { election }\end{array}$ & 15,809 & 52.64 & 13,076 & 43.54 & 30,561 & 49.0 & $\begin{array}{l}\text { NDC } \\
\text { stronghold }\end{array}$ \\
\hline $\begin{array}{l}\text { 31 August 2010 Atiwa by-election } \\
\text { 31 January 2019 Ayawaso West }\end{array}$ & 6,190 & 22.9 & 20,282 & 75.0 & 27,540 & 53.3 & $\begin{array}{l}\text { NPP } \\
\text { stronghold }\end{array}$ \\
\hline Wuogon by-election & 5,341 & 30.52 & 12,041 & 68.80 & 17,589 & 19.83 & $\begin{array}{l}\text { NPP } \\
\text { stronghold }\end{array}$ \\
\hline 2009 Akwatia by-election & 15,860 & - & 17,900 & - & - & - & $\begin{array}{l}\text { NPP } \\
\text { stronghold }\end{array}$ \\
\hline
\end{tabular}

Source: author's compilation from EC website; media sources, 2020

Table 5: "Violent-free" by-elections results and voter turnout from 2005 to 2019

\begin{tabular}{|l|l|l|l|l|l|l|l|}
\hline $\begin{array}{l}\text { Parliamentary and constituency by- } \\
\text { election }\end{array}$ & $\begin{array}{l}\text { NDC } \\
\text { votes }\end{array}$ & $\begin{array}{l}\text { \% of } \\
\text { votes }\end{array}$ & $\begin{array}{l}\text { NPP } \\
\text { votes }\end{array}$ & \% Votes & $\begin{array}{l}\text { Voter } \\
\text { Turn out }\end{array}$ & $\begin{array}{l}\text { \% voter } \\
\text { turnout }\end{array}$ & $\begin{array}{l}\text { Nature of } \\
\text { constituency }\end{array}$ \\
\hline $\begin{array}{l}\text { 4 April 2005 Tamale Central by- } \\
\text { election }\end{array}$ & 29,081 & 68.3 & & & & & $\begin{array}{l}\text { NDC } \\
\text { stronghold }\end{array}$ \\
\hline 13 March 2007 Nkoranza by-election & 5,694 & 35.6 & 10,179 & 63.7 & 19,490 & 80.5 & $\begin{array}{l}\text { NPP } \\
\text { stronghold }\end{array}$ \\
\hline $\begin{array}{l}\text { 25 October 2006 Offinso South by- } \\
\text { election }\end{array}$ & 10,666 & 33.7 & 20,763 & 65.5 & 31,690 & 70.7 & $\begin{array}{l}\text { NPP } \\
\text { stronghold }\end{array}$ \\
\hline 23 January 2007 Fomena by-election & 2,003 & 17.21 & 9,525 & 81.84 & 11,785 & 69.03 & $\begin{array}{l}\text { NPP } \\
\text { stronghold }\end{array}$ \\
\hline 7 April 2009 Jirapa by-election & 12,518 & 79.1 & 3,181 & 20.9 & 16,360 & & $\begin{array}{l}\text { NDC } \\
\text { stronghold }\end{array}$ \\
\hline $\begin{array}{l}\text { 6 February 2013 Akatsi South by- } \\
\text { election }\end{array}$ & 12,079 & & $* 66$ & & & 49.02 & $\begin{array}{l}\text { NDC } \\
\text { stronghold }\end{array}$ \\
\hline 16 July 2016 Abetifi by-election & $* 7$ & $*$ & 14,015 & 89.9 & 15,577 & 35.55 & $\begin{array}{l}\text { NPP } \\
\text { stronghold }\end{array}$ \\
\hline 26 February 2013 Buem by-election & 9,366 & 84.68 & $*$ & & 11,247 & 30.0 & $\begin{array}{l}\text { NDC } \\
\text { stronghold }\end{array}$ \\
\hline $\begin{array}{l}\text { 29 March 2016 Abuakwa North by- } \\
\text { election }\end{array}$ & $* 8$ & & 10,033 & 89.60 & 11,307 & 28.22 & $\begin{array}{l}\text { NPP } \\
\text { stronghold }\end{array}$ \\
\hline
\end{tabular}

Source: author's compilation from EC website; media sources, 2020.

\footnotetext{
${ }^{6}$ NPP boycotted all the by-elections held in 2013 in view of 2012 Supreme Court election petition challenging the results.

${ }^{7} \mathrm{NDC}$ refused to participate in the election citing proximity of the by-election to the up-coming general election in 2016.

${ }^{8} \mathrm{NDC}$ pulled out of the by-election on sympathy grounds given the circumstances that led to the death of the MP J.B. Danquah.
} 


\section{Party patterns and margin of victory}

In this section I compare the margin of victory between NDC and NPP in "violent" byelection with "violent-free" parliamentary election in the same constituency. I test the following hypothesis: a) is the margin of victory between NDC and NPP smaller or higher in the case of "violent" by-election compared with "violent-free" parliamentary election in the same constituency or in competitive or stronghold constituency?

In 2012 parliamentary election, NDC lost its traditional seat in the Talensi constituency to NPP with 2,261 votes representing $11.24 \%$ defeat margin. Although it recaptured the seat in a "violent" by-election in 2015 with $12.37 \%$ margin of victory, its performance in "violent-free" parliamentary election in 2016 was higher recorded at $14.55 \%$ margin of victory. The NDC margin of victories in 2015 by-election and 2016 parliamentary election were more than 10\%, although NPP won the seat once in 2012 with $11.24 \%$ margin of victory.

On the other hand, NPP's performance in NDC stronghold Asawase constituency kept dwindling at both parliamentary and by-elections. NPP lost at $21.7 \%$ margin of defeat in 2005 "violent" by-election. Its margin of defeat in "violent-free" parliamentary election in 2004 was $6.6 \%$, and worsened in 2008 parliamentary election at $14.5 \%$. The NPP however, won the 2010 "violent" Atiwa by-election as its traditional seat with $52.1 \%$ margin of victory while in opposition. The performance was however lower than its margin of victory in "violent-free" parliamentary election in 2008 recorded at $53.7 \%$.

Table 6: NDC's margin of victory and voter turnout

\begin{tabular}{|l|l|l|l|l|l|}
\hline $\begin{array}{l}\text { Parliamentary and constituency by-election } \\
\text { results }\end{array}$ & $\begin{array}{l}\text { NDC } \\
\text { votes }\end{array}$ & $\begin{array}{l}\text { \% of } \\
\text { votes }\end{array}$ & $\begin{array}{l}\text { Voter } \\
\text { Turn out }\end{array}$ & $\begin{array}{l}\text { \% voter } \\
\text { turnout }\end{array}$ & $\begin{array}{l}\text { Competitive } \\
\text { stronghold }\end{array}$ \\
\hline 2016 Talensi parliamentary & 12,874 & 41.68 & 31,700 & 72.0 & NDC stronghold \\
\hline 2012 Talen parliamentary & 9,119 & 33.22 & 27,450 & $\mathrm{Na}$ & Swing to NPP \\
\hline 7 July 2015 Talensi by-election & 10,366 & 42.31 & 24,499 & $\mathrm{Na}$ & NDC stronghold \\
\hline 2004 Asawase parliamentary & 33,541 & 49.7 & 67,485 & 84 & NDC stronghold \\
\hline 2008 Asawase parliamentary & 36,557 & 56.7 & 64,943 & 69.1 & NDC stronghold \\
\hline 21 April, 2005 Asawase by- election & 31,017 & 60.4 & 51,635 & 64.29 & NDC stronghold \\
\hline 2004 Odododiodoo parliamentary & 35,634 & 52.4 & 67,994 & 83.3 & NDC stronghold \\
\hline 2008 Odododiodoo parliamentary & 34,182 & 55.7 & 61,613 & 65.9 & NDC stronghold \\
\hline $\begin{array}{l}\text { 30 August 2005 Odododiodoo } \\
\text { by-election }\end{array}$ & 26,841 & 57.9 & 46,991 & 57.6 & NDC stronghold \\
\hline 2012 Chereponi parliamentary & 10,565 & 46.58 & 22,683 & $\mathrm{Na}$ & NDC stronghold \\
\hline 2008 Chereponi parliamentary & 7,648 & 43.6 & 18,615 & 80.0 & NDC stronghold \\
\hline $\begin{array}{l}\text { 29 September 2009 Chereponi } \\
\text { by-election }\end{array}$ & 8,239 & 50.9 & 16,186 & 71.3 & NDC stronghold \\
\hline 2008 Atiwa parliamentary & 7,851 & 22.7 & 34,931 & 74.2 & NPP stronghold \\
\hline 2010 Atiwa by-election & 6,190 & 22.9 & 27,540 & 53.3 & NPP stronghold \\
\hline 2012 parliamentary (Atiwa West) & 5,984 & 25.84 & 23,160 & $\mathrm{Na}$ & NPP stronghold \\
\hline 2012 Ayawaso West Wuogon parliamentary & 30,116 & 47.63 & 63,232 & $\mathrm{Na}$ & NPP stronghold \\
\hline 2016 Ayawaso West Wuogon parliamentary & 22,534 & 39.63 & 57,053 & 64 & NPP stronghold \\
\hline $\begin{array}{l}\text { 31 January 2019 Ayawaso West Wuogon by- } \\
\text { election }\end{array}$ & 5,341 & 30.52 & 17,589 & 19.83 & NPP stronghold \\
\hline
\end{tabular}




\begin{tabular}{|l|l|l|l|l|l|}
\hline 2012 Akwatia parliamentary & 20,471 & 50.44 & 40,586 & $\mathrm{Na}$ & NDC stronghold \\
\hline 2004 Akwatia parliamentary & 17,484 & 45.5 & 37,135 & 90.2 & NDC stronghold \\
\hline 2009 Akwatia by-election & 15,860 & & 17,900 & & \\
\hline 2004 Wulensi parliamentary election & 9,864 & 43.7 & 23,754 & 89.0 & Competitive \\
\hline 20 February 2003 Wulensi by-election & 7,303 & 45.0 & 16,798 & 58.1 & Competitive \\
\hline 2000 Wulensi parliamentary election & 9,537 & 54.4 & & & \\
\hline
\end{tabular}

Source: author's compilation from EC website; media sources, 2020

NPP obtained $38.28 \%$ margin of victory in 2019 "violent" by-election in its stronghold constituency Ayawaso West Wuogon. The NDC performance in the constituency dwindles from $2.67 \%$ defeat margin in 2012 to $17.69 \%$ in 2016 "violent-free" parliamentary elections, and $38.28 \%$ in a "violent" by-election in 2019. However, NDC performance in its stronghold constituency Odododiodoo remains progressive from $6 \%$ to $14.2 \%$ margin of victories in "violent-free" parliamentary election in 2004 and 2008 respectively to $18.1 \%$ in "violent" byelection in 2005. The analysis shows that the margin of victory between NDC and NPP is smaller in "violent" by-election compared with "violent-free" parliamentary election in the same constituency.

Table 7: NPP's margin of victory and voter turnout

\begin{tabular}{|l|l|l|l|l|l|}
\hline $\begin{array}{l}\text { Parliamentary and constituency by-election } \\
\text { results }\end{array}$ & $\begin{array}{l}\text { NPP } \\
\text { votes }\end{array}$ & $\begin{array}{l}\text { \% Vote } \\
\text { s }\end{array}$ & $\begin{array}{l}\text { Voter } \\
\text { Turn out }\end{array}$ & $\begin{array}{l}\text { \% voter } \\
\text { turnout }\end{array}$ & $\begin{array}{l}\text { Competitive } \\
\text { stronghold }\end{array}$ \\
\hline 2016 Talensi parliamentary & 8,382 & 27.13 & 31,700 & 72.0 & NDC stronghold \\
\hline 2012 Talen parliamentary & 11,380 & 41.46 & 27,450 & $\mathrm{Na}$ & Swing to NPP \\
\hline 7 July 2015 Talensi by-election & 6,845 & 29.94 & 24,499 & $\mathrm{Na}$ & NDC stronghold \\
\hline 2004 Asawase parliamentary & 29,067 & 43.1 & 67,485 & 84 & NDC stronghold \\
\hline 2008 Asawase parliamentary & 27,168 & 42.2 & 64,943 & 69.1 & NDC stronghold \\
\hline 21 April, 2005 Asawase by- election & 19,875 & 38.7 & 51,635 & 64.29 & NDC stronghold \\
\hline 2004 Odododiodoo parliamentary & 31,546 & 46.4 & 67,994 & 83.3 & NDC stronghold \\
\hline 2008 Odododiodoo parliamentary & 25,495 & 41.5 & 61,613 & 65.9 & NDC stronghold \\
\hline $\begin{array}{l}\text { 30 August 2005 Odododiodoo } \\
\text { by-election }\end{array}$ & 18,464 & 39.8 & 46,991 & 57.6 & NDC stronghold \\
\hline 2012 Chereponi parliamentary & 11,680 & 51.49 & 22,683 & $\mathrm{Na}$ & NDC stronghold \\
\hline 2008 Chereponi parliamentary & 9,188 & 52.3 & 18,615 & 80.0 & NDC stronghold \\
\hline $\begin{array}{l}\text { 29 September 2009 Chereponi } \\
\text { by-election }\end{array}$ & 7,416 & 45.8 & 16,186 & 71.3 & NDC stronghold \\
\hline 2008 Atiwa parliamentary & 26,423 & 76.4 & 34,931 & 74.2 & NPP stronghold \\
\hline 2010 Atiwa by-election & 20,282 & 75.0 & 27,540 & 53.3 & NPP stronghold \\
\hline 2012 parliamentary (Atiwa West) & 17,176 & 74.16 & 23,160 & $\mathrm{Na}$ & NPP stronghold \\
\hline 2012 Ayawaso West Wuogon parliamentary & 31,807 & 50.30 & 63,232 & $\mathrm{Na}$ & NPP stronghold \\
\hline 2016 Ayawaso West Wuogon parliamentary & 32,591 & 57.32 & 57,053 & 64 & NPP stronghold \\
\hline $\begin{array}{l}\text { 31 January 2019 Ayawaso West Wuogon by- } \\
\text { election }\end{array}$ & 12,041 & 68.80 & 17,589 & 19.83 & NPP stronghold \\
\hline 2012 Akwatia parliamentary & 19,914 & 49.07 & 40,586 & $\mathrm{Na}$ & NDC stronghold \\
\hline 2004 Akwatia parliamentary & 19,386 & 51.6 & 37,135 & 90.2 & NDC stronghold \\
\hline 2009 Akwatia by-election & 17,900 & & 17,900 & & \\
\hline
\end{tabular}




\begin{tabular}{|l|l|l|l|l|l|}
\hline 2004 Wulensi parliamentary election & 10,476 & 46.4 & 23,754 & 89.0 & Competitive \\
\hline 20 February 2003 Wulensi by-election & 8,197 & 50.5 & 16,798 & 58.1 & Competitive \\
\hline 2000 Wulensi parliamentary election & 6,884 & 39.3 & & & Competitive \\
\hline
\end{tabular}

Source: author's compilation from EC website, media sources, 2020

\section{Conclusion}

The paper has argued the intensity of by-election violence, thuggery and impunity, and implications on candidates' selection and representation in Ghana. It analysed voter turnout and margin of victory during "violent" by-election compared with "violent-free" parliamentary election in the same constituency, and "violent-free" by-elections in other constituencies. The analysis shows a reduction of voter turnout and margin of victory in "violent" by-elections compared with "violent-free" by-election among contesting political parties, notably NDC and NPP. The violence is primarily caused by the political parties using the party vigilantes commonly referred to "foot-soldiers" who serve as the rank and file of the parties.

I attribute by-election violence due to seemingly weak commitment by successive governments to link electoral injustice and impunity to the conduct of democratic election and law maintenance in Ghana. While the political behaviour of the ruling coalition and their network such as party thugs incite by-election violence; the actions and inactions of the law enforcement agencies, i.e. the police and national security operatives have aggravated the violence. The apparent weak regime of criminal prosecution of electoral offences only bolsters others who would cause trouble. One would have thought that by-election which involves a constituency at a time will be peaceful and easy to organise compared with general election, considering the growing democratic credentials of Ghana. This proves otherwise. The challenge speaks to institutionalisation, electoral reforms and the de-facto electoral competition of a simple majority benefiting from the entire political establishment. A fellow-up research is therefore required to interrogate the dynamism of by-election security breaches by the security agencies and the threats they pose to candidate selection. 


\section{References}

Adolfo, E.V., Söderberg Kovacs, M., Nyström, D. \& Utas, M. 2012. Electoral violence in Africa. Nordiska Afrikainstitutet.

Agbaje, A. \& Adejumobi, S.J.A.D. 2006. Do Votes Count? 1 The Travails of Electoral Politics in Nigeria. 31(3):25-44-25-44.

Amankwaah, C. 2013. Election-related violence: The case of Ghana. Nordiska Afrikainstitutet.

Asamoah, K.J.J.o.A. \& Studies, A. 2020. Addressing the problem of political vigilantism in Ghana through the conceptual lens of wicked problems. 55(3):457-471.

Asante, K.J.A.P.M. 2012. Beyond Ghana's Election 2012: The Challenges of Rescuing a Country in Crisis.

Atwood, R.J.B.P. 2012. How the EU can support peaceful post-election transitions of power: lessons from Africa.

Aubyn, F. \& Abdallah, M.J.J.o.A.E. 2013. Sustaining peace and stability in Ghana-appraising the role of the National Election Security Task Force in the 2012 elections. 12(2):132-153.

Ayee, J.R.J.S.A.J.o.I.A. 2017. Ghana's elections of 7 December 2016: A post-mortem. 24(3):311-330.

Baker, B.J.J.o.C.A.S. 2002. When the Bakassi boys came: Eastern Nigeria confronts vigilantism. 20(2):223-244.

Boafo-Arthur, K. 2006. Voting for Democracy in Ghana: The 2004 Elections in Perspective Vol. Freedom Publications, Accra.

Bob-Milliar, G.M.J.A.s.q. 2014. Party youth activists and low-intensity electoral violence in Ghana: a qualitative study of party foot soldiers' activism. 15(1):125.

BBC, 2019. Ghana opposition boycott Ayawaso West Wuogon by-elections after shooting incidence injure seven https://www.bbc.com/pidgin/tori-47075963 .[Accessed 6 April 2020].

Centre for African Democratic Affairs, 2018. Violence in Africa Region, http://www.divaportal.org/smash/get/diva2:1192338/FULLTEXT01.pdf [Accessed January 2020].

CDD, 2020. Electoral violence and political vigilantism in Ghana: evidence from selected communities

https://info.undp.org/docs/pdc/Documents/GHA/Electoral\%20Violence\%20and\%20Political\%20 Vigilantism\%20Research.pdf [Accessed April 2020]

CDD, 2019. Report on Ayawaso West Wuogon constituency by-election, https://www.cddgh.org/codeo-final-report-on-observation-of-the-ayawaso-west-wuogonconstituency-by-election-2019/. [Accessed 10 May 2020]

CDD, 2005a. CDD-Ghana's Statement on Odododiodio by-election https://www.ghanaweb.com/GhanaHomePage/NewsArchive/CDD-Ghana-s-Statement-on-

Odododiodio-by-election-89343. [Accessed 10 May 2020].

CDD, 2005b. Statement on the Thursday April 212005 Asawase constituency parliamentary bye-election. $\quad$ https://www.ghanaweb.com/GhanaHomePage/NewsArchive/Asawase-byeelection-was-fair-and-transparent-but-not-free-from-fear-CDD-80156. [Accessed 10 May 2020]. CDD, 2015. CDD-Ghana statement on Talensi by-election. http://citifmonline.com/2015/07/cddghana-condemns-violence-at-talensi-by-elections/ [Accessed 10 May 2020].

CODEO, 2017a. Communique. on violence. http://www.codeoghana.org/assets/downloadables/CODEO\%20Communique_6April17.pdf.

[Accessed 12 May 2020]. 
CDD, 2017. Afro barometer survey

http://afrobarometer.org/sites/default/files/summary_results/ab_r6_afrobarometer_global_release highlights8.pdf [Accessed 28 April 2020].

CODEO, 2017b. statement on the menace of political party vigilantism in Ghana. http://www.codeoghana.org/assets/downloadables/The\%20Menace\%20of\%20Political\%20Party \%20Vigilantism_\%20Reflections\%20from\%20Koforidua.pdf [Accessed 12 May 2020].

Citinewsroom, 2017 http://citifmonline.com/2017/10/govt-must-take-blame-for-party-vigilanteproblems-christian-council/ [Accessed 5 March 2020].

Daddieh, C.K. \& Bob-Milliar, G.M. 2014. Ghana: The African exemplar of an institutionalized two-party system? In Party systems and democracy in Africa. Springer. 107-128.

Danso, K. \& Lartey, E.J.M.e.-r.v.f.d.s.i.G. 2012. Democracy on a knife's edge: Ghana's democratization processes, institutional malaise and the challenge of electoral violence. 33.

Darkwah, L.J.M.E.-R.V.f.D.S.i.G. 2012. Gender, elections and violence: Pricing women out of democracy in Ghana.277-305.

Dery, D.J.P.S. 2000. Agenda setting and problem definition. 21(1):37-47.

Dunning, T.J.J.o.C.R. 2011. Fighting and voting: Violent conflict and electoral politics. 55(3):327-339.

Entman, R.M. 1993. Framing: Toward clarification of a fractured paradigm.

Fischer, J.J.I.W.p. 2002. Electoral conflict and violence. 1.

Frempong, A.K.J.P., Governance, \& Ghana, D.i. 2019. Change and Continuity in Ghana's Electoral Politics (1951-2016).259.

Gerber, M.M. \& Jackson, J. 2017. Justifying violence: legitimacy, ideology and public support for police use of force. Psychology, crime \& law. 23(1):79-95.

Gyampo, R.E., Graham, E. \& Asare, B.E.J.A.R. 2017. Political vigilantism and democratic governance in Ghana's Fourth Republic. 44(2):112-135.

Gyimah-Boadi, E. 2007. Political parties, elections and patronage: Random thoughts on neopatrimonialism and African democratization.

Gyimah-Boadi, E. \& Debrah, E. 2008. Political parties and party politics.

Graphiconline.com, 2015, https://www.youtube.com/watch?v=4Zfj9uD7mUo.[Accessed 5 March 2020].

Graphiconline.com, 2009. Chereponi violence, https://www.graphic.com.gh/features/opinion/election-violence-to-vote-or-not.html[Accessed 29 April 2020].

Ghanabusinessnews.com, 2011. Attorney General briefs Parliament on the catastrophes of Atiwa bye election, https://www.ghanabusinessnews.com/2011/07/08/attorney-general-briefsparliament-on-the-catastrophes-of-atiwa-bye-election/ [Accessed 29 April 2020].

GhanaWeb, 2019. https://www.ghanaweb.com/GhanaHomePage/NewsArchive/AWW-Fullrecommendations-of-the-Emile-Short-Commission-782207 Accessed 29 April 2020].

GhanaWeb, 2009a. Parliament condemns violence during Akwatia election, https://www.ghanaweb.com/GhanaHomePage/NewsArchive/Parliament-condemns-violenceduring-Akwatia-election-167617. [Accessed 29 April 2020].

GhanaWeb, 2009b. Atiwa by-election and aftermath, https://www.ghanaweb.com/GhanaHomePage/features/The-Atiwa-By-Election-And-Aftermath189805. [Accessed 22 April 2020]. 
GhanaWeb, 2010a. Police delegation to investigate Atiwa violence, https://www.ghanaweb.com/GhanaHomePage/NewsArchive/Police-delegation-to-investigateAtiwa-violence-190253. [Accessed 22 April 2020].

GhanaWeb, 2010b. AG briefs Parliament on Atiwa bye election, https://www.ghanaweb.com/GhanaHomePage/NewsArchive/AG-briefs-Parliament-on-Atiwabye-election-213171, [Accessed 20 July 2020].

GhanaWeb, 2005. MP calls for investigations into violence during Asawase election, https://www.ghanaweb.com/GhanaHomePage/NewsArchive/MP-calls-for-investigations-intoviolence-during-Asawase-election-81114, [Accessed 20 July 2020].

Huntington, S.P. 1991. Democracy's third wave. Journal of democracy. 2(2):12-34.

Ijon, F.B.J.A.R.J.o.A. \& Sciences, S. 2020. Election security and violence in Ghana: The case of Ayawaso West Wougon and Talensi By-elections.32-46.

Issafrica.org, 2009. Political vigilantism threatens stability in Ghana, https://issafrica.org/isstoday/political-vigilantism-threatens-stability-in-ghana [Accessed 23 June 2020].

Jinadu, A. 2014. Lessons from Electoral Management and Processes in West Africa.

Jonah, K. 2005. Election 2004 and the Policy Challenge of the NPP Government.

Khan, M. 2010. Political settlements and the governance of growth-enhancing institutions.

Kumah-Abiwu, F.J.C. \& Politics, C. 2017. Issue framing and electoral violence in Ghana: a conceptual analysis. 55(2):165-186.

Kwarteng, C.J.T.R.T. 2014. Swords into ploughshares: The judicial challenge of Ghana's 2012 presidential election results. 103(1):83-93.

Laakso, L. 2019. Electoral violence and political competition in Africa. In Oxford Research Encyclopedia of Politics.

Lindberg, S.I.J.D. 2003. 'It's Our Time to" Chop"': Do Elections in Africa Feed NeoPatrimonialism rather than Counter-Act It? 10(2):121-140.

Lund, C.J.J.o.M.A.S. 2003. 'Bawku is still volatile': ethno-political conflict and state recognition in Northern Ghana.587-610.

Mueller, S.D.J.J.o.C.A.S. 2011. Dying to win: Elections, political violence, and institutional decay in Kenya. 29(1):99-117.

Myjoyonline.com, 2015. Talensi by-election: EC rubbishes NPP claims it is conspiring with NDC. https://www.myjoyonline.com/news/talensi-by-election-ec-rubbishes-npp-claims-it-isconspiring-with-ndc/, [Accessed 5 July 2020].

National Commission for Civic Education, 2011. https://nccegh.org/wpcontent/uploads/2020/07/Research-on-Election-Conflict-in-Ghana-May-2011.pdf [Accessed 20 July 2020].

Nina, D.J.A.S.R. 2000. Dirty Harry is back: vigilantism in South Africa-The (re) emergence of the 'good'and 'bad'community. 9(1):18-28.

Ninsin, K.A. 2006. Political parties and political participation in Ghana. KAS.

Ninsin, K.A.J.I.i.G.s.e.p. 2016. Elections and representation in Ghana's democracy.115-134.

Ninsin, K.A.J.T.A.U. \& Africa, N.S.f.D.i. 2008. West Africa's integration: The logic of history and culture. 123 .

Oduro, F., Mohammed, A. \& Ashon, M. 2014. A dynamic mapping of the political settlement in Ghana.

Paalo, S.A.J.I.J.o.P. \& Studies, D. 2017. Political party youth wings and political violence in sub-Sahara Africa: A case of Ghana. 8(1):1-14. 
Parku, S.J.A., Policy Paper. 2014. Who says elections in Ghana are 'free and fair'? 15. Rapoport, D.C. \& Weinberg, L. 2000. Elections and violence.

Read, J.S.J.I. \& Quarterly, C.L. 1962. Ghana: The Criminal Code, 1960.272-279. UNDP. 2011. Understanding electoral violence in Asia. Author Bangkok.

WANEP, 2019. Situation Updates of the Ayawaso West Wuogon By-Election Violence. https://wanep.org/wanep/files/2019/Feb/Final_Quick_Update-Ayawaso_By-Election_01-0220191.pdf. [Accessed 25 July 2020]. 
Appendix 1: List of political vigilante groups in Ghana since independence

\begin{tabular}{|c|c|c|c|c|}
\hline Period and name of the groups & $\begin{array}{l}\text { Party } \\
\text { Affiliation }\end{array}$ & Location & Sphere of Influence & $\begin{array}{l}\text { No. of } \\
\text { Groups } \\
\text { per party }\end{array}$ \\
\hline \multicolumn{5}{|l|}{ Post-independence: 1957-1992 } \\
\hline Hoodlums & CPP & Accra & Greater Accra & \\
\hline Tokyo Joe boys & CPP & Accra & Greater Accra & \\
\hline Veranda Boys & CPP & Accra & Greater Accra & CPP (3) \\
\hline Action troopers & UP & Accra & Greater Accra & UP (1) \\
\hline Mobsquad & PNDC & Accra & Greater Accra & \\
\hline $\begin{array}{l}\text { Committee for the Defense of the } \\
\text { Revolution (CDR) }\end{array}$ & PNDC & Nationwide & Nationwide & \\
\hline $\begin{array}{l}\text { Workers Defense Committees } \\
\text { (WDCs) }\end{array}$ & PNDC & Nationwide & Nationwide & \\
\hline $\begin{array}{l}\begin{array}{l}\text { People's } \\
\text { (PDCs) }\end{array} \\
\end{array}$ & PNDC & Nationwide & Nationwide & PNDC (4) \\
\hline \multicolumn{5}{|l|}{1992 under the Fourth Republic } \\
\hline Aluta Boys & NDC & Tamale & Northern Region & \\
\hline Tohazie & NDC & Tamale & Northern Region & \\
\hline Pentagon & NDC & Tamale & Northern Region & \\
\hline Gbewaa Youth & NDC & Tamale, Yendi & Northern Region & \\
\hline Azorka Boys & NDC & Tamale & Northern region & \\
\hline 66 Bench & NDC & Tamale & Northern Region & \\
\hline Al Qaeda & NDC & Tamale & Northern Region & \\
\hline Al Jazeera & NDC & Tamale & Northern Region & \\
\hline NATO Forces & NDC & Tamale & Northern Region & \\
\hline Rasta Boys & NDC & $\begin{array}{l}\text { Agbogbloshie } \\
\text { (Accra) }\end{array}$ & Greater Accra & \\
\hline The Hawks & NDC & Kumasi & Ashanti Region & \\
\hline The Dragons & NDC & - & Brong Ahafo Region & \\
\hline Lions & NDC & - & - & \\
\hline Eastern Mambas & NDC & & Eastern Region & \\
\hline Asamankese Forces & NDC & Asamankese & Eastern Region & \\
\hline Taliban Boys & NDC & $\begin{array}{l}\text { Konkonba Market } \\
\text { (Accra) }\end{array}$ & Greater Accra Region & \\
\hline Sese Group & $\mathrm{NDC}$ & Nima (Accra) & Greater Accra & NDC (26) \\
\hline Zongo Caucus & NDC & Tamale & $\begin{array}{l}\text { Northern, Ashanti and } \\
\text { Greater Accra Regions }\end{array}$ & \\
\hline Supreme, & NDC & - & - & - \\
\hline Mahama Boys & NDC & - & - & \\
\hline Badariba & NDC & - & - & \\
\hline Bindiriba & $\mathrm{NDC}$ & - & - & \\
\hline Bukurisung & NDC & - & - & \\
\hline Veranda Boys & NDC & - & - & \\
\hline Bukurosun & NDC & - & - & \\
\hline Basuka Boys & NDC & - & - & \\
\hline Hazi & NPP & - & - & \\
\hline
\end{tabular}




\begin{tabular}{|l|l|l|l|l|}
\hline Eagle Forces & NPP & - & - & \\
\hline Ashanti vigilante group & NPP & - & - & \\
\hline Green Mambas & NPP & - & - & \\
\hline Nima Boys & NPP & - & - & \\
\hline Salifu Eleven & NPP & - & - & \\
\hline Invisible Forces & NPP & Accra & Greater Accra & \\
\hline Bamba Boys & NPP & Wenchi & BrongA hafo & \\
\hline Delta Forces & NPP & Kumasi and Accra & $\begin{array}{l}\text { Greater Accra and } \\
\text { Ashanti Regions }\end{array}$ & \\
\hline Bolga Bulldogs & NPP & $\begin{array}{l}\text { Navrongo, } \\
\text { Sandema, Bawku, } \\
\text { Bolga, and } \\
\text { Techiman }\end{array}$ & $\begin{array}{l}\text { Upper East and Brong } \\
\text { Ahafo and }\end{array}$ & \\
\hline Kandahar Boys & Tamale & Tamale & Northern Region & \\
\hline Burma Camp & NPP & Damongo & Northern Region & \\
\hline Baafira & NPP & - & $\begin{array}{l}\text { Upper East Region } \\
\text { Upper West Region }\end{array}$ & NPP (14) \\
\hline The Rock & NPP & NP & \\
\hline
\end{tabular}

Source: Author's compilation from media reports; adoption from Aning, 2018; Edu-Afful and AlloteyPappoe, 2016; CDD, 2016. 